\title{
65. OXYGEN ISOTOPE STUDY OF CONTINUOUS SCRAPE SAMPLES FROM SITE 480
}

\author{
N. J. Shackleton and M. A. Hall, The Godwin Laboratory for Quaternary Research, \\ University of Cambridge, Cambridge, England
}

\section{INTRODUCTION}

During the cleaning of the HPC core surfaces from Hole 480 for photography, the material removed was conserved carefully in approximately $10 \mathrm{~cm}$ intervals (by $\mathrm{K}$. Kelts); this material was made available to us in the hope that it would be possible to obtain oxygen isotope stratigraphy for the site. The samples were, of course, somewhat variable in size, but the majority were probably between 5 and $10 \mathrm{~cm}^{3}$. Had this been a normal marine environment, such sample sizes would have contained abundant planktonic foraminifers together with a small number of benthics. However, this is clearly not the case, for many samples contained no foraminifers, whereas others contained more benthics than planktonics.

Among the planktonic foraminifers the commonest species are Globigerina bulloides, Neogloboquadrina dutertrei, and $N$. pachyderma. A few samples contain a more normal fauna with Globigerinoides spp. and occasional Globorotalia spp. Sample 480-3-3, 20-30 cm contained Globigerina rubescens, isolated specimens of which were noted in a few other samples in Cores 3, 4, and 5. This is a particularly solution-sensitive species; in the open Pacific it is only found widely distributed at horizons of exceptionally low carbonate dissolution, such as the last glacial-to-interglacial transition.

Among the benthic species the fauna is dominated by Bólivina spp. and Uvigerina, forms well illustrated by Phleger (1964). In a few samples the Uvigerina were heavily costate; in Sample 480-8-2, 60-80 cm these were associated with other species not generally found at the site and with mineral grains in a foraminiferal sand that is probably redeposited. For some tens of centimeters above this sample, somewhat worn-looking specimens of similar costate uvigerinids were noted, and because of this association we avoided analyzing the costate uvigerinids mixed with others on the ground that they may be reworked. However, in Sample 480-4-3, 90-100 cm we did analyze such specimens from a sample that contained mineral grains; the isotope value is comparable with adjacent analyses of normal specimens.

In addition to foraminifers, the coarse fraction of nearly all samples contains fish debris. Occasional samples contain mineral grains; these are more abundant in samples in Core 8 and below. It seems likely that foraminifers were removed from the barren samples by dissolution, since some samples contain only very few partly dissolved foraminifers.
An important general point may be made concerning these samples, one that certainly has a bearing on sampling for future studies. There is considerable variation between samples at the present sampling interval (which must be of the order of a century). It would be useful to ascertain whether this reflects very rapid changes in water chemistry (and if so, how rapid) or whether we are seeing thin turbidites. Probably the most useful procedure would be to take a series of small samples at very close intervals (on the order of $1 \mathrm{~mm}$ apart) for carbonate analysis over a short time interval, to ascertain the depth-scale on which the variability occurs.

\section{ISOTOPE DATA}

Oxygen isotope data are given in Table 1 and in Figure 1 are plotted as a function of depth below sea floor. All data are expressed relative to the PDB standard (Epstein et al., 1951), using analytical techniques similar to those described by Shackleton and Opdyke (1973).

The bottom temperature today at Site 480 is about $6.5^{\circ} \mathrm{C}$ and the salinity about $34.55 \%$ (Roden and Groves, 1959). Although Craig and Gordon (1965) did not analyze any water samples from very nearby for ${ }^{18} \mathrm{O}$ content, we may estimate from their Station V111-5 at the appropriate depth that the water would stand at about $-0.2 \%$ on the PDB scale. The data given by Shackleton (1974) and a considerable amount of additional data enable us to predict an ${ }^{18} \mathrm{O}$ content of about $+2.3 \pm 0.2 \%$ for Uvigerina today. By analogy with other cores, we would expect that during the last glacial maximum values about $1.6 \%$ heavier than this would be recorded. Although we were unable to analyze any Uvigerina from the upper two cores, we find transitional values in Core 3 and several excursions to $+4.1 \%$ in Core 4 . Thus the Stage $2 / 1$ boundary must lie in Core 3 , a placement supported by the exceptional preservation peak noted at Sample 480-3-3, 20-30 cm.

In a number of samples in Cores 3 to 5 , bolivinids were analyzed; the scattered data suggest that they may, like uvigerinids, calcify close to isotopic equilibrium. All values through to the base of Core 5 are consistent with a Stage 2 age (between 24,000 and 14,000 y. B.P.). If we ignore the single apparently interglacial analysis (probably unreliable) from Sample 480-6-1, 80-90 cm, values in Cores 6 and 7 are consistent with deposition in Stage 3 . We did not analyze material from the apparently reworked deposit in Core 8 , and there were very few foraminifers in Core 9. In Core 10, two consecutive sam- 
Table 1. Oxygen and carbon isotope data for Site $480 .^{a}$

\begin{tabular}{|c|c|c|c|c|}
\hline $\begin{array}{l}\text { Core/Section } \\
\text { (interval in } \mathrm{cm} \text { ) }\end{array}$ & $\begin{array}{l}\text { Depth below } \\
\text { Sea Floor } \\
\text { (m) }\end{array}$ & $\delta^{18} \mathrm{O}$ & $\delta^{13} \mathrm{C}$ & Species \\
\hline $1-2,100-120$ & 2.50 & $+2.84^{*}$ & $-1.40^{*}$ & Bolivina spp. \\
\hline $2-1,30-40$ & 5.05 & $+3.06^{*}$ & $-0.62^{*}$ & Uvigerina $\mathrm{sp}$. \\
\hline $2-1,80-90$ & 5.55 & $+3.38^{*}$ & $-1.20^{*}$ & Bolivina spp. \\
\hline $2-3,30-40$ & 8.05 & +2.65 & -0.16 & Trifarina sp. \\
\hline $3-1,0-20$ & 9.50 & +2.72 & -2.28 & Bolivina sp. \\
\hline $3-1,20-40$ & 9.70 & +2.46 & -2.28 & Bolivina sp. \\
\hline $3-1,40-50$ & 9.90 & +2.79 & -2.17 & Bolivina sp. \\
\hline $3-1,60-70$ & 10.10 & +3.20 & -1.21 & Bolivina spp. \\
\hline $3-1,70-80$ & 10.20 & +3.26 & -0.60 & Uvigerina $\mathrm{sp}$. \\
\hline $3-1,70-80$ & 10.20 & $+2.65^{*}$ & $-1.91^{*}$ & Bolivina spp. \\
\hline $3-1,80-90$ & 10.30 & $+2.66^{*}$ & $-2.11^{*}$ & Bolivina spp. \\
\hline $3-1,90-100$ & 10.40 & +3.10 & -0.62 & Uvigerina sp. \\
\hline $3-1,110-120$ & 10.60 & +3.37 & -0.99 & Uvigerina sp. \\
\hline $3-1,120-130$ & 10.70 & +3.30 & -1.10 & Uvigerina sp. \\
\hline $3-1,130-140$ & 10.80 & +3.34 & -1.38 & Uvigerina sp. \\
\hline $3-2,20-30$ & 11.20 & +2.61 & -1.06 & Bolivina sp. \\
\hline $3-2,60-70$ & 11.60 & +2.33 & -1.09 & Bolivina sp. \\
\hline $3-2,80-90$ & 11.80 & +3.14 & -1.55 & Bolivina sp. \\
\hline $3-2,90-100$ & 11.90 & +3.20 & -1.79 & Bolivina sp. \\
\hline $3-2,110-120$ & 12.10 & +3.40 & -1.04 & Bolivina sp. \\
\hline $3-2,110-120$ & 12.10 & +3.38 & -0.66 & Uvigerina $\mathrm{sp}$. \\
\hline $3-2,130-140$ & 12.30 & +3.47 & -1.25 & Uvigerina sp. \\
\hline $3-2,140-150$ & 12.40 & +3.45 & -1.25 & Uvigerina sp. \\
\hline $3-3,0-10$ & 12.50 & +4.04 & -0.60 & Uvigerina $\mathrm{sp}$. \\
\hline $3-3,10-20$ & 12.60 & +3.92 & -0.62 & Uvigerina sp. \\
\hline $3-3,20-30$ & 12.70 & +3.89 & -0.85 & Uvigerina sp. \\
\hline $3-3,30-36$ & 12.80 & +3.77 & -0.70 & Uvigerina sp. \\
\hline $3-3,50-60$ & 13.00 & +3.65 & -1.31 & Uvigerina sp. \\
\hline $3-3,70-80$ & 13.20 & +3.67 & -0.97 & Uvigerina sp. \\
\hline $3-3,80-90$ & 13.30 & +3.75 & -1.38 & Bolivina sp. \\
\hline $3-3,90-100$ & 13.40 & +3.70 & -1.10 & Bolivina sp. \\
\hline $3-3,110-120$ & 13.60 & +3.45 & -1.25 & Bolivina sp. \\
\hline $3-3,120-127$ & 13.70 & +3.55 & -1.74 & Bolivina sp. \\
\hline $4-1,40-60$ & 14.65 & +3.98 & -1.40 & Uvigerina sp. \\
\hline $4-1,60-75$ & 14.85 & +4.03 & -0.52 & Uvigerina sp. \\
\hline $4-1,75-90$ & 15.00 & +4.12 & -1.01 & Uvigerina sp. \\
\hline $4-1,90-110$ & 15.15 & +4.09 & -0.74 & Uvigerina $\mathrm{sp}$. \\
\hline $4-1,110-130$ & 15.35 & +4.19 & -0.53 & Bolivina sp. \\
\hline $4-1,130-150$ & 15.55 & +4.02 & -0.57 & Uvigerina $\mathrm{sp}$. \\
\hline $4-2,0-4$ & 15.75 & +3.69 & -0.49 & Bolivina sp. \\
\hline $4-2,10-20$ & 15.85 & +3.82 & -0.13 & Uvigerina sp. \\
\hline $4-2,20-30$ & 15.95 & +3.95 & -0.45 & Uvigerina $\mathrm{sp}$. \\
\hline $4-2,20-30$ & 15.95 & +3.79 & -0.42 & Bolivina sp. \\
\hline $4-2,30-40$ & 16.05 & +4.09 & -0.84 & Uvigerina $\mathrm{sp}$. \\
\hline $4-2,40-50$ & 16.15 & +3.89 & -0.68 & Uvigerina sp. \\
\hline $4-2,60-70$ & 16.35 & +3.78 & -0.72 & Uvigerina $\mathrm{sp}$. \\
\hline $4-2,90-100$ & 16.65 & +4.10 & -0.36 & Uvigerina sp. \\
\hline $4-2,100-110$ & 16.75 & +4.11 & -0.56 & Uvigerina sp. \\
\hline $4-2,110-120$ & 16.85 & +3.84 & -0.76 & Bolivina sp. \\
\hline $4-2,120-130$ & 16.95 & +4.01 & -0.50 & Uvigerina $\mathrm{sp}$. \\
\hline $4-2,130-140$ & 17.05 & +3.93 & -0.61 & Uvigerina sp. \\
\hline $4-2,140-150$ & 17.15 & +3.70 & -1.00 & Bolivina sp. \\
\hline $4-3,0-10$ & 17.25 & +3.98 & -0.58 & Bolivina sp. \\
\hline $4-3,10-20$ & 17.35 & +4.08 & -0.56 & Bolivina sp. \\
\hline $4-3,20-30$ & 17.45 & +3.79 & -0.42 & Bolivina sp. \\
\hline $4-3,30-40$ & 17.55 & +4.07 & -0.56 & Bolivina sp. \\
\hline $4-3,40-50$ & 17.65 & +3.94 & -0.53 & Bolivina sp. \\
\hline $4-3,60-80$ & 17.85 & +3.89 & -0.48 & Uvigerina $\mathrm{sp}$. \\
\hline $4-3,80-90$ & 18.05 & +4.15 & -0.83 & Uvigerina $\mathrm{sp}$. \\
\hline $4-3,80-90$ & 18.05 & +4.14 & -1.09 & Bolivina sp. \\
\hline $4-3,90-100$ & 18.15 & +3.99 & -0.42 & Uvigerina $\mathrm{sp}$. \\
\hline $4-3,130-150$ & 18.55 & +3.72 & -0.57 & Uvigerina sp. \\
\hline $5-1,15-30$ & 19.15 & +3.98 & -0.82 & Uvigerina sp. \\
\hline $5-1,40-50$ & 19.40 & +4.04 & -0.41 & Uvigerina sp. \\
\hline $5-1,50-60$ & 19.50 & +4.04 & -0.78 & Uvigerina $\mathrm{sp}$. \\
\hline $5-1,60-70$ & 19.60 & +3.85 & -0.40 & Bolivina sp. \\
\hline $5-1,70-80$ & 19.70 & +4.00 & -0.81 & Bolivina sp. \\
\hline $5-1,80-90$ & 19.80 & +3.97 & -0.58 & Uvigerina sp. \\
\hline
\end{tabular}

Table 1. (Continued).

\begin{tabular}{|c|c|c|c|c|}
\hline $\begin{array}{c}\text { Core/Section } \\
\text { (interval in cm) }\end{array}$ & $\begin{array}{l}\text { Depth below } \\
\text { Sea Floor } \\
\text { (m) }\end{array}$ & $\delta^{18} \mathrm{O}$ & $\delta^{13} \mathrm{C}$ & Species \\
\hline $5-1,90-100$ & 19.90 & +3.84 & -0.28 & Uvigerina $\mathrm{sp}$ \\
\hline $5-1,100-110$ & 20.00 & +3.92 & -0.83 & Bolivina sp. \\
\hline $5-2,80-90$ & 21.30 & +3.79 & -0.71 & Bolivina sp. \\
\hline $5-3,0-10$ & 22.00 & +3.73 & -1.00 & Bolivina sp. \\
\hline $5-3,30-40$ & 22.30 & +3.70 & -0.88 & Bolivina sp. \\
\hline $5-3,60-70$ & 22.60 & +3.91 & -0.55 & Uvigerina $\mathrm{sp}$ \\
\hline $6-1,0-10$ & 23.75 & +3.96 & -0.65 & Bolivina sp. \\
\hline $6-1,20-30$ & 23.95 & +3.60 & -1.06 & Bolivina sp. \\
\hline $6-1,30-40$ & 24.05 & +3.62 & -1.22 & Bolivina sp. \\
\hline $6-1,40-60$ & 24.15 & +3.61 & -2.20 & Bolivina sp. \\
\hline $6-1,40-60$ & 24.15 & +3.66 & -1.58 & Uvigerina $\mathrm{sp}$ \\
\hline $6-1,80-90$ & 24.55 & $+2.56^{*}$ & $-0.91^{*}$ & Uvigerina sp. \\
\hline $6-1,100-120$ & 24.75 & +4.05 & -0.25 & Uvigerina $\mathrm{sp}$. \\
\hline $6-2,130-150$ & 26.55 & +3.56 & -1.07 & Bolivina sp. \\
\hline $7-1,70-80$ & 29.20 & +3.61 & -1.24 & Bulimina sp. \\
\hline $7-2,20-30$ & 30.20 & +3.75 & -0.39 & Bolivina sp. \\
\hline $7-2,30-40$ & 30.30 & +3.68 & -0.52 & Bolivina sp. \\
\hline $7-2,100-110$ & 31.00 & +3.69 & -1.65 & Bolivina sp. \\
\hline $7-2,110-120$ & 31.10 & +3.85 & -0.54 & Bolivina sp. \\
\hline $7-2,120-130$ & 31.20 & +3.74 & -0.55 & Bolivina sp. \\
\hline $7-2,130-140$ & 31.30 & +3.81 & -1.62 & Bolivina sp. \\
\hline $7-2,140-150$ & 31.40 & +3.62 & -1.52 & Bolivina sp. \\
\hline $7-3,0-10$ & 31.60 & +3.60 & -1.16 & Bolivina sp. \\
\hline $7-3,40-50$ & 32.00 & +3.54 & -1.43 & Bolivina sp. \\
\hline $7-3,80-90$ & 32.40 & +3.36 & -1.00 & Bolivina sp. \\
\hline $7-3,90-100$ & 32.50 & +3.54 & -0.82 & Bolivina sp. \\
\hline $7-3,110-120$ & 32.70 & +3.77 & -0.97 & Bolivina sp. \\
\hline $8-1,120-135$ & 34.45 & +3.97 & -0.72 & Bolivina sp. \\
\hline $8-2,40-60$ & 35.15 & +3.78 & -1.24 & Uvigerina $\mathrm{sp}$. \\
\hline $10-2,10-20$ & 44.35 & $+2.32^{*}$ & $-1.71^{*}$ & Bolivina sp. \\
\hline $10-2,20-30$ & 44.45 & $+2.32^{*}$ & $-1.59^{*}$ & Bolivina sp. \\
\hline $11-1,40-60$ & 47.90 & +2.48 & -0.62 & Uvigerina $\mathrm{sp}$. \\
\hline $13-1,68-80$ & 62.43 & +3.85 & -1.13 & Uvigerina sp. \\
\hline $14-1,50-60$ & 67.00 & +3.13 & -1.45 & Uvigerina sp. \\
\hline
\end{tabular}

Note: The analyses asterisked were made immediately after a machine breakdown; it seems likely, in the light of their plotted position in Figure 1 , that they are unreliable. It is our normal procedure to vacuum-roast samples immediately before analysis (in batches of 10 samples); these samples had been roasted before the machine breakdown, which was only fully cured after three weeks. We suspect that vacuum-roasting may decompose a small percentage of the calcite of the foraminifers to $\mathrm{CaO}$, which would be expected to take up atmospheric moisture and $\mathrm{CO}_{2}$ to give a small amount of carbonate of a different isotopic composition. Whether or not this is the correct explanation, we consider that the asterisked analyses should be disregarded.

a Values are expressed with reference to the PDB standard of Epstein et al. (1951).

ples (480-10-2, 10-20 cm and 480-10-2, 20-30 cm) yielded apparently full interglacial values, but unfortunately it was subsequently discovered that they (and other samples asterisked in Table 1) were analyzed when the mass spectrometer was not working reliably. In any case, it is difficult to make good use of oxygen isotope stratigraphy when there are long intervals without data. At the present time it does not appear that further isotope studies would enable us unambiguously to correlate the sediments of Site 480 with the standard marine oxygen isotope stratigraphy. If an oxygen isotope stratigraphy were obtained for the siliceous diatoms (Labeyrie, 1973; Mikkelsen et al., 1978), then this might justify further work on the foraminifers. 


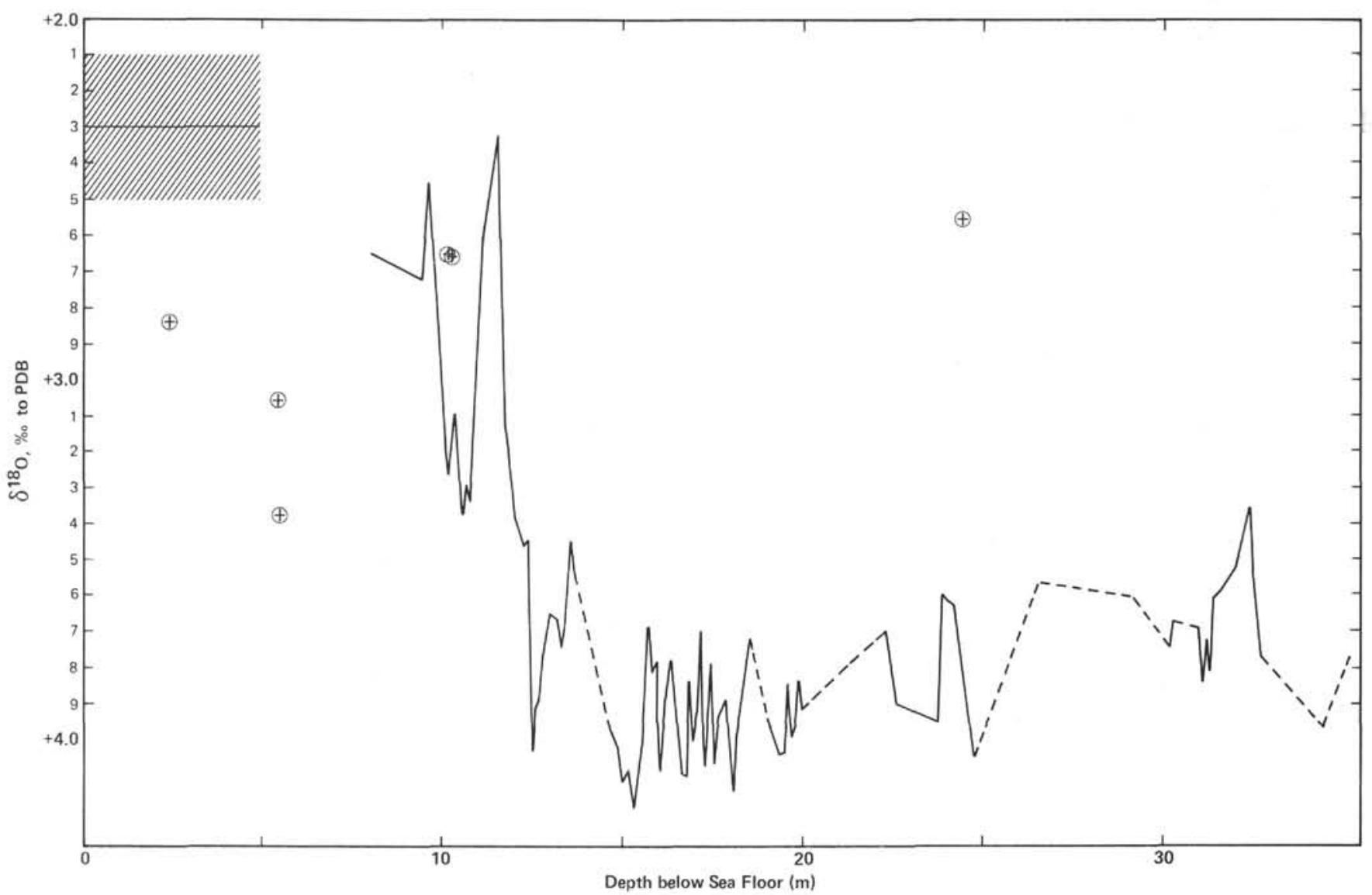

Figure 1. Oxygen isotope record of bentpic foraminifers from Site 480 . The hatched area shows the predicted value for Stage 1 (Holocene) specimens. The circled points represent a set of measurements made immediately after a machine breakdown; these are now regarded as untrustworthy.

\section{DISCUSSION}

If, as suggested earlier, Stage 2 extends from within Core 3 to the base of Core 5 , the interval from 14,000 to 24,000 y. B.P. (using the chronology proposed by Pastouret et al., 1978) may be represented by about 10.3 meters of sediment between Samples 480-3-3, $0 \mathrm{~cm}$ and $480-5-3,140 \mathrm{~cm}$, giving a sediment accumulation rate of about $1 \mathrm{~m} / 10^{3} \mathrm{y}$. This suggests that the variation observed in Core 4 has a characteristic time on the order of $1000 \mathrm{y}$. Recent detailed analyses of a core from the Panama Basin region (Shackleton, Hall, and Imbrie, in prep.) suggest the existence of variation on a similar time scale there. Detailed work in this part of Site 480 could prove particularly rewarding in understanding these changes. Oxygen isotope studies in the Camp Century ice core from the Greenland ice sheet (Dansgaard et al., 1971) have revealed very substantial variability on about the same time scale in that record; the time scale involved is too short for these to be explicable in terms of changes in the altitude of the ice sheet, so that quite substantial temperature changes must be represented over Greenland. It remains to be investigated whether these temperature changes were of sufficient magnitude to cause significant fluctuations in ocean isotopic composition; Site 480 is one of the few sections available in which this time interval could be studied in detail in ocean sediments.

\section{CONCLUSIONS}

1. The Holocene section of Site 480 , extending roughly 10 meters, contains insufficient benthic foraminifera for isotopic analysis. However, glacial age sediments and those deposited during the glacial-to-Holocene transition do contain benthic foraminifers at most horizons, suggesting that the deep water was relatively more oxygenated then than it is today.

2 . The oxygen isotope record preserved in benthic foraminifers contains a uniquely detailed record of Isotope Stage 2 and of the Stage 2/1 boundary interval. There is considerable variability, with a period on the order of 1000 y., during Stage 2.

3. Taken on its own, oxygen isotope stratigraphy is of little use in the lower part of the section because it is impossible to recover a continuous record. However, if it becomes possible to obtain an isotope record from the siliceous material or if other detailed stratigraphic techniques are applicable, isotopic analyses in benthic foraminifers deeper in the hole may be justified.

\section{ACKNOWLEDGMENTS}

We are very grateful for the opportunity to make a preliminary study of these unique sediments. The Hydraulic Piston Corer used to recover them is clearly revolutionizing many aspects of paleoceanography and we were privileged to be among the first to have the benefit of its use. We warmly thank Kerry Kelts for his foresight in preserving so carefully material that would normally have been wasted. We 
are grateful to Sandra Bromble, Lloyd Burckle, and Linda Heusser for helpful reviews of the manuscript. Research was supported by NERC under grant GR3/3606.

\section{REFERENCES}

Craig, H., and Gordon, L. I., 1965. Deuterium and oxygen-18 variations in the ocean and the marine atmosphere. In Tongiorgi, E. (Ed.), Stable Isotopes in Oceanographic Studies and Paleotemperatures: Pisa (Consiglio Nazionale delle Ricerche), pp. 9-130.

Dansgaard, W., Johnsen, S. J., Clausen, H. B., and Langway, C. C., Jr., 1971. Climatic record revealed by the Camp Century ice core. In Turekian, K. T. (Ed.), Late Cenozoic Glacial Ages: New Haven and London (Yale University Press), pp. 37-56.

Epstein, S., Buchsbaum, R., Lowenstam, H. A., and Urey, H. C., 1951. Carbonate-water isotopic temperature scale. Geol. Soc. Am. Bull., 64:1315-1326.

Labeyrie, L., 1973. New approach to surface palaeotemperatures using ${ }^{18} \mathrm{O} /{ }^{16} \mathrm{O}$ ratios in silica of diatom frustules. Nature, 248:40-41.

Mikkelsen, N., Labeyrie, L., and Berger, W. H., 1978. Silica oxygen isotopes in diatoms: A 20,000 yr record in deep-sea sediments. Nature, 271:536-538.
Pastouret, L., Chamley, H., Delibrias, G., Duplessy, J.-C., and Thiede, J., 1978. Late Quaternary climatic changes in Western tropical Africa deduced from deep-sea sedimentation off the Niger Delta. Oceanol. Acta, 1:21-232.

Phleger, F. B., 1964. Patterns of living benthonic Foraminifera, Gulf of California. In van Andel, Tj. H., and Shor, G. G. (Eds.), Marine Geology of the Gulf of California: Am. Assoc. Pet. Geol. Memoir 3:377-394.

Roden, G. I., and Groves, G. W., 1959. Recent oceanographic investigations in the Gulf of California. J. Mar. Res., 18:10-35.

Shackleton, N. J., 1974. Attainment of isotopic equilibrium between ocean water and the benthonic foraminifera genus Uvigerina: Isotopic changes in the ocean during the last glacial. Colloq. Int. C.N.R.S., 219:203-210.

Shackleton, N. J., and Opdyke, N. D., 1973. Oxygen isotope and palaeomagnetic stratigraphy of Equatorial Pacific core V28-238: Oxygen isotope temperatures and ice volumes on a $10^{5}$ year and $10^{6}$ year scale. Quat. Res., 3:39-55. 